\title{
Effectiveness of Character Education Model in Unimed to Improve Students Creativity
}

\author{
Pardomuan Nauli Josip Mario Sinambela \\ Mathematics Department \\ Universitas Negeri Medan \\ Medan, Indonesia \\ pardomuannjmsinambela@gmail.com
}

\author{
Yasaratodo Wau \\ Non Formal Education Department \\ Universitas Negeri Medan \\ Medan, Indonesia \\ yasaratodo@gmail.com
}

\author{
Sahat Siagian \\ Electrical Engineering Education Department \\ Universitas Negeri Medan \\ Medan, Indonesia \\ sahat.sgn61@gmail.com \\ Tri Andri Hutapea \\ Mathematics Department \\ Universitas Negeri Medan \\ Medan, Indonesia \\ triandh_a19@yahoo.com
}

\begin{abstract}
This research is a continuation of previous research. The result of previous research was character education model in Unimed. This research studied about the effectiveness of the model. Validity of components of the character education model including accompanying instruments for data gathering were evaluated before evaluating the effectiveness of the model. Research method used in this research was descriptive method. The result of this study showed that the character education model from previous research are needed to be revised.
\end{abstract}

\section{Keywords - character; students creativity}

\section{INTRODUCTION}

Cultivating students' character may be done through instructional or other scientific activities. One of many patterns for cultivating character is by promoting character through extracurricular activities in students' organization. This way, apart from achieving academic and creative achievements, character development becomes an additional outcome of students' activities. Based on earlier research, there is a model of character education developed in Universitas Negeri Medan that was intended to improve students' creativity. The research showed that the character education pattern resulted in desired outcome. Hence, it is necessary to review the effectiveness of university's policies about character education related to this model.

\section{LITERATURE REVIEW}

\section{A. Character Education Model}

Some condition for extracurricular education that support the success of character education implementation are: 1) university's culture and interpersonal practices, which guarantee that students are treated with care and respect. 2) Lecturer, staff become good character model for students, 3) Providing opportunity for students to have autonomy and influence in university's management, 4) Providing opportunity for students to reflect, argue or collaborate in order to find solutions for moral issues, 5) sharing vision and sense of collectively and responsibility, 6) social skill training, 7) providing more opportunity for students participating in any occasion that may raise moral attitude [1].

Each students organization's member selection is an important factor for supporting character development and improving students' creativity. This selection includes creativity test and characters self-assessment to find initial condition for character and creativity of each student organization member candidates. Before the students who pass the selection process officially become member of the organization, they will need to attend a training that is character education for students organization. This programme is designed to prepare each student organization member to have an experience about implementation of character education and creativity expression. With initial character and creativity owned by each student organization member added with experiences from attending character education programme, all member are responsible for the existence of the organization, and have to design annual work programme which based on six character education pillars in order to improve students organization member's creativity.

Indicators of work programme of each student organization have to match programmes from Ministry of research and higher education. For example, an indication for a student organization have improved members' creativity is the quantity of their achievement in seven kinds of Program Kreativitas Mahasiswa - PKM (students creativity programme) each year. In this phase, each student organization runs the annual work programme as planned. Of course, for each implementation of the programme must be based on six pillars of character education which has positive impact in improving creativity.

The team of Vice Rector for students affair will monitor and evaluate the student organization annual work programme 
regularly. In this phase, the team will match the implementation and its result of each annual work program with the initial plan. Each incompatibility between the implementation and plan will be seen as input for following activity. In this phase, each student organization clarifies each input from monitoring and evaluation team as things that are needed to be corrected in next annual programme. The character education design scheme for Unimed's student organization is shown as follow.

Students organization

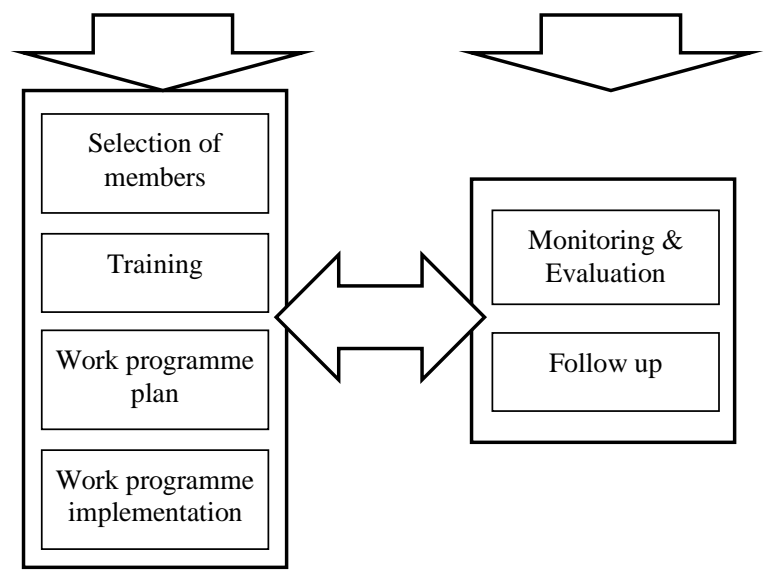

Figure 1. Unimed's students organization Character Education

Each students organization's member selection is an important factor for supporting character development and improving students' creativity. This selection includes creativity test and characters self-assessment to find initial condition for character and creativity of each student organization member candidates. Before the students who pass the selection process officially become member of the organization, they will need to attend a training that is character education for students organization. This programme is designed to prepare each student organization member to have an experience about implementation of character education and creativity expression. With initial character and creativity owned by each student organization member added with experiences from attending character education programme, all member are responsible for the existence of the organization, and have to design annual work programme which based on six character education pillars in order to improve students organization member's creativity.

Indicators of work programme of each student organization have to match programmes from Ministry of research and higher education. For example, an indication for a student organization have improved members' creativity is the quantity of their achievement in seven kinds of Program Kreativitas Mahasiswa - PKM (students creativity programme) each year. In this phase, each student organization runs the annual work programme as planned. Of course, for each implementation of the programme must be based on six pillars of character education which has positive impact in improving creativity.

The team of Vice Rector for students affair will monitor and evaluate the student organization annual work programme regularly. In this phase, the team will match the implementation and its result of each annual work program with the initial plan. Each incompatibility between the implementation and plan will be seen as input for following activity. In this phase, each student organization clarifies each input from monitoring and evaluation team as things that are needed to be corrected in next annual programme.

\section{B. Effectiveness of Character Education}

According to Thomas Lickona, there are 10 criteria for an effective character education, that is 1) applying character education concept that is accepted widely, 2) generating greater benefit for students who attend the programme, compare to those who did not, 3) strengthening educational community, 4) employing practitioners based on research, 5) class or university attitude are improved after implementing the programme, 6) providing observable differences on students individually, 7) Students testify that the programme has positive effect for them, 8) mobilising peer culture on virtue side, 9) helping students to become effective parent when they have children in the future, 10) Helping students to use all intellectual resource and their culture, including their tradition and beliefs, when making moral decision.[2], [3], [4]

On the other hand, checking whether a character education model is effective may be done by evaluating the model itself. According to Kirkpatrick there are four level of evaluation that is 1) Reaction, 2) Learning, 3) Behaviour, and 4) Results. Table 1 shows how these two views are compatible and compliment each other. [5]

Table 1 Compatibility of Kirkpatrick Evaluation Level and Lickona criteria

\begin{tabular}{|l|l|}
\hline \multicolumn{1}{|c|}{ Kirkpatrick } & \multicolumn{1}{|c|}{ Lickona } \\
\hline Reaction & $\begin{array}{l}\text { Applying character education concept that } \\
\text { are accepted widely }\end{array}$ \\
\cline { 2 - 3 } & $\begin{array}{l}\text { generating greater benefit for students who } \\
\text { attend the programme, compare to those who } \\
\text { did not }\end{array}$ \\
\hline Learning & strengthening educational community \\
\cline { 2 - 3 } & employing practitioners based on research \\
\hline & $\begin{array}{l}\text { class or university attitude are improved } \\
\text { after implementing the programme }\end{array}$ \\
\cline { 2 - 3 } & $\begin{array}{l}\text { Students testify that the programme has } \\
\text { positive effect for them }\end{array}$ \\
\cline { 2 - 3 } & $\begin{array}{l}\text { Helping students to use all intellectual } \\
\text { resource and their culture, including their } \\
\text { tradition and beliefs, when making moral } \\
\text { decision }\end{array}$ \\
\cline { 2 - 3 } & $\begin{array}{l}\text { providing observable differences on students } \\
\text { individually }\end{array}$ \\
\cline { 2 - 2 } mobilising peer culture on virtue side \\
\hline Results & $\begin{array}{l}\text { helping students to become effective parent } \\
\text { when they have children in the future }\end{array}$ \\
\hline
\end{tabular}

Based on Table 1 effectiveness of character education model is based on Kirpatrick evaluation level that is modified related to Lickona criteria. In this study the character education model will be said effective if it satisfies the reaction, learning, and behaviour level. Result level is not used in this research because the result seen in this research is limited on respondent individual attitude changes. 


\section{METHOD}

This research used descriptive method, and in order to support this method researchers developed valid instruments and instructional tools for character education. This research evaluated the effectiveness of the model by using a modified version of Kirkpatrick evaluation model by adjusting it with Lickona's criteria for the effectiveness of character.

\section{RESULT AND DISCUSSION}

The result of this research is valid tools and instrument for character education model, which will be discussed further as follow.

\section{A. Students' Response}

Students' response for the character education model were collected by using a questionnaire, with result as shown in Table 2.

Table 2. Students' Response

\begin{tabular}{|c|c|c|c|c|c|}
\hline \multirow[t]{2}{*}{ No } & \multirow[t]{2}{*}{ Responded Aspect } & \multicolumn{2}{|c|}{$\begin{array}{c}\text { Number of } \\
\text { students }\end{array}$} & \multicolumn{2}{|c|}{ Percentage } \\
\hline & & Happy & $\begin{array}{c}\text { Not } \\
\text { happy }\end{array}$ & Happy & $\begin{array}{c}\text { Not } \\
\text { happy }\end{array}$ \\
\hline \multirow[t]{2}{*}{1} & $\begin{array}{l}\text { Students' feeling } \\
\text { about character } \\
\text { education model }\end{array}$ & 46 & 19 & 70.51 & 29.49 \\
\hline & & New & $\begin{array}{l}\text { Not } \\
\text { new }\end{array}$ & New & $\begin{array}{l}\text { Not } \\
\text { new }\end{array}$ \\
\hline \multirow[t]{2}{*}{2} & $\begin{array}{l}\text { Students' feeling } \\
\text { about character } \\
\text { education model }\end{array}$ & 45 & 20,00 & 69.23 & 30.77 \\
\hline & & $\begin{array}{c}\text { Interest } \\
\text { ed }\end{array}$ & $\begin{array}{c}\text { Not } \\
\text { interest } \\
\text { ed }\end{array}$ & $\begin{array}{c}\text { Interes } \\
\text { ted }\end{array}$ & $\begin{array}{c}\text { Not } \\
\text { interest } \\
\text { ed }\end{array}$ \\
\hline 3 & $\begin{array}{l}\text { Students' opinion } \\
\text { about interest on } \\
\text { developing } \\
\text { creativity }\end{array}$ & 55 & 10 & 84.62 & 15.38 \\
\hline 4 & $\begin{array}{l}\text { Students' opinion } \\
\text { about their } \\
\text { involvement in the } \\
\text { organization }\end{array}$ & 57 & 8 & 87.69 & 12.31 \\
\hline \multirow[t]{2}{*}{5} & $\begin{array}{l}\text { Students' opinion } \\
\text { about being an } \\
\text { example for good } \\
\text { attitude }\end{array}$ & 55 & 10 & 84.62 & 15.38 \\
\hline & & Clear & $\begin{array}{c}\text { Unclea } \\
r\end{array}$ & Clear & $\begin{array}{c}\text { Unclea } \\
r\end{array}$ \\
\hline 6 & $\begin{array}{l}\text { Students' opinion } \\
\text { about nurturing } \\
\text { approach by } \\
\text { supervisor }\end{array}$ & 45 & 20 & 69.23 & 30.77 \\
\hline 7 & $\begin{array}{l}\text { Students' opinion } \\
\text { about service } \\
\text { quality of creativity } \\
\text { development }\end{array}$ & 45 & 20 & 69.23 & 30.77 \\
\hline \multirow[t]{2}{*}{8} & $\begin{array}{l}\text { Students opinion } \\
\text { about Unimed's } \\
\text { character education } \\
\text { pillar }\end{array}$ & 50 & 15 & 76.92 & 23.08 \\
\hline & & $\begin{array}{c}\text { attracte } \\
d\end{array}$ & $\begin{array}{c}\text { Not } \\
\text { attract } \\
\text { ed }\end{array}$ & $\begin{array}{c}\text { attract } \\
\text { ed }\end{array}$ & $\begin{array}{c}\text { Not } \\
\text { attract } \\
\text { ed }\end{array}$ \\
\hline 9 & Students opinion & 47 & 18 & 72.31 & 27.69 \\
\hline
\end{tabular}

\begin{tabular}{|l|l|l|l|l|l|}
\hline $\begin{array}{l}\text { about Unimed's } \\
\text { character education } \\
\text { model }\end{array}$ & & & & \\
\hline
\end{tabular}

Based on data from the questionnaire percentage of students who are happy with the character education model is $70.51 \%$. The greatest percentage for positive response was in students interest to be involved in the organization which is $87.69 \%$, while the smallest percentage for positive response was in the clarity of students nurturing aspect and the clarity of creativity development service which is $69.23 \%$

\section{B. Supervisor Response}

Table 3 shows data of supervisors' response questionnaire.

Table 3. Supervisors' Response

\begin{tabular}{|c|c|c|c|c|c|}
\hline \multirow[t]{2}{*}{ No } & \multirow[t]{2}{*}{$\begin{array}{c}\text { Responded } \\
\text { Aspect }\end{array}$} & \multicolumn{2}{|c|}{$\begin{array}{l}\text { Supervisors' } \\
\text { Response }\end{array}$} & \multicolumn{2}{|c|}{ Percentage } \\
\hline & & Happy & $\begin{array}{c}\text { Not } \\
\text { happy }\end{array}$ & Happy & $\begin{array}{c}\text { Not } \\
\text { happy }\end{array}$ \\
\hline \multirow[t]{2}{*}{1} & $\begin{array}{l}\text { Supervisors' } \\
\text { feeling about } \\
\text { character } \\
\text { education model }\end{array}$ & 8 & 1 & 85.19 & 14.81 \\
\hline & & New & $\begin{array}{l}\text { Not } \\
\text { new }\end{array}$ & New & $\begin{array}{l}\text { Not } \\
\text { new }\end{array}$ \\
\hline \multirow[t]{2}{*}{2} & $\begin{array}{l}\text { Supervisors' } \\
\text { feeling about } \\
\text { character } \\
\text { education model } \\
\end{array}$ & 7 & 2 & 75.93 & 24.07 \\
\hline & & $\begin{array}{c}\text { Intereste } \\
\quad d\end{array}$ & $\begin{array}{c}\text { Not } \\
\text { interes } \\
\text { ted }\end{array}$ & $\begin{array}{c}\text { Interes } \\
\text { ted }\end{array}$ & $\begin{array}{c}\text { Not } \\
\text { interest } \\
\text { ed }\end{array}$ \\
\hline 3 & $\begin{array}{l}\text { Supervisors' } \\
\text { opinion about } \\
\text { students' interest } \\
\text { on developing } \\
\text { creativity }\end{array}$ & 5 & 4 & 55.56 & 44.44 \\
\hline 4 & $\begin{array}{l}\text { Supervisors' } \\
\text { opinion about } \\
\text { students' } \\
\text { involvement in } \\
\text { the organization }\end{array}$ & 8 & 1 & 88.89 & 11.11 \\
\hline \multirow[t]{2}{*}{5} & $\begin{array}{l}\text { Supervisors' } \\
\text { opinion about } \\
\text { being an } \\
\text { example for } \\
\text { good attitude }\end{array}$ & 6 & 3 & 66.67 & 33.33 \\
\hline & & Clear & $\begin{array}{c}\text { Uncle } \\
\text { ar }\end{array}$ & Clear & $\begin{array}{c}\text { Unclea } \\
r\end{array}$ \\
\hline 6 & $\begin{array}{l}\text { Supervisor's } \\
\text { opinion about } \\
\text { students' } \\
\text { attitude related } \\
\text { to character } \\
\text { building }\end{array}$ & 5 & 4 & 55.56 & 44.44 \\
\hline 7 & $\begin{array}{l}\text { Supervisor's } \\
\text { opinion about } \\
\text { the quality of } \\
\text { students' } \\
\text { creativity } \\
\text { development } \\
\text { service }\end{array}$ & 7 & 2 & 77.78 & 22.22 \\
\hline 8 & $\begin{array}{l}\text { Supervisor } \\
\text { opinion about } \\
\text { Unimed's }\end{array}$ & 9 & 0 & 100.00 & 0.00 \\
\hline
\end{tabular}




\begin{tabular}{|c|l|c|c|c|c|}
\hline & $\begin{array}{l}\text { character } \\
\text { education pillar }\end{array}$ & attracted & $\begin{array}{c}\text { Not } \\
\text { attract } \\
\text { ed }\end{array}$ & $\begin{array}{c}\text { attract } \\
\text { ed }\end{array}$ & $\begin{array}{c}\text { Not } \\
\text { attract } \\
\text { ed }\end{array}$ \\
\hline 9 & $\begin{array}{l}\text { Supervisor } \\
\text { opinion about } \\
\text { Unimed's } \\
\text { character } \\
\text { education model }\end{array}$ & 7 & 2 & 77.78 & 22.22 \\
\hline
\end{tabular}

Data from students organization supervisor questionaire shows that percentage of students who feel happy with the character education model is $85.19 \%$. The greatest percentage for positive response is for supervisor understand Unimed character education clearly which is $100 \%$, while the smallest percentage for positive response is supervisor opinion about students' interest to develop their creativity and supervisor opinion about students' attitude related to character building which is $55.56 \%$. This data shows that there are some revision still needed for character education so that the expected result might be realized.

\section{CONCLUSION}

Data gathered in this study shows that there is difference between what was intended with the actual results in other words expectation has not match the reality perfectly yet. Hence character education model is still needed to be revised. So, there will be further research needed for current model in order to improve it so the expected result may be achieved.

\section{REFERENCES}

[1] Melinda,CB., Berkowitz MW. What Work in Character Education ? Leadership For Students Activities, vol. 34, no 2, pp. 1-7. October 2005

[2] Schaps, E., Watson, M. and Lewis, C. A sense of community is key to effectiveness in fostering character education. Journal of Staff Development Spring. 1996

[3] Lickona, Thomas. Educating for Character: How Our Schools can Teach Respect and Responsibility. Bantam Books: New York. 1991

[4] Curwin, R. The healing power of altruism. Educational Leadership November, 1993.

[5] Wirawan, Evaluasi. PT Raja Grafindo Persada: Jakarta. 2016 